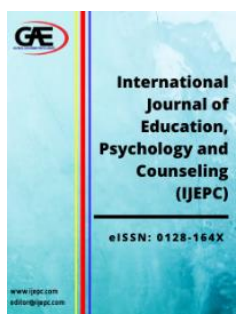

\author{
INTERNATIONAL JOURNAL OF \\ EDUCATION, PSYCHOLOGY \\ AND COUNSELLING \\ (IJEPC) \\ www.ijepc.com
}

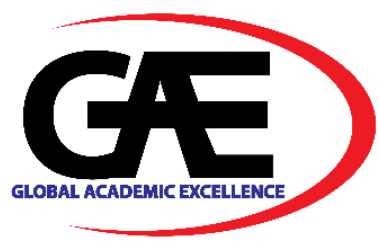

\title{
SYSTEMATIC LITERATURE REVIEW: USING ENGLISH MOVIES TO DEVELOP ESL LEARNERS' SPEAKING CONFIDENCE
}

\author{
Nurul Hidayah Awang Asim ${ }^{1 *}$, Wardatul Akmam $\operatorname{Din}^{2 *}$, Kamsilawati Kamlun ${ }^{3}$, Suyansah Swanto ${ }^{4}$ \\ $1 \quad$ Faculty of Psychology and Education, Universiti Malaysia Sabah, Malaysia \\ Email: hidayahawangasim@gmail.com \\ 2 Faculty of Psychology and Education, Universiti Malaysia Sabah, Malaysia \\ Email: wardadin@ums.edu.my \\ 3 Centre for Promotion of Knowledge and Literature, Universiti Malaysia Sabah, Malaysia \\ Email: kamsi@ums.edu.my \\ $4 \quad$ Faculty of Psychology and Education, Universiti Malaysia Sabah, Malaysia \\ Email: suyansah@ums.edu.my \\ Corresponding Author
}

\section{Article Info:}

\section{Article history:}

Received date: 11.09 .2021

Revised date: 10.10 .2021

Accepted date: 15.11.2021

Published date: 30.11 .2021

\section{To cite this document:}

Awang Asim, N. H., Din, W. A., Kamlun, K., \& Swanto, S. (2021). Systematic Literature Review: Using English Movies To Develop ESL Learners' Speaking Confidence. International Journal of Education, Psychology and Counseling, 6 (43), 205-218.

DOI: $10.35631 /$ IJEPC.643017

\begin{abstract}
:
Can English movies improve ESL learners' speaking confidence? What are the suggested ways to implement English movies in acquiring speaking confidence for ESL learners? The main goal of the review is to study how English movies can aid ESL learners in higher education who struggle with speaking confidence. The search phrases used in these databases were "English movies" AND "confidence" and "English movies" AND "speaking" in order to acquire a list of relevant research. The first aspect that we will discuss in this review is the issue of low speaking confidence that is usually caused by language anxiety, lack of self-esteem and fear of judgement among other reasons. The articles collected represent language learners from different age ranges such as young kindergarten learners until university level learners. In addition to that, we will also investigate further into the research from the databases available for English movies that can be utilized as instructional aid for ESL learners to acquire speaking confidence. To find relevant research publications, four databases were used: ProQuest, Science Direct, Scopus and JSTOR. The review was carried out by using the UMS Library's access to subscribed databases. As part of this systematic review, we devised a search strategy to collect relevant literature. Researchers over the years have differing opinions on the current situation. The majority of the study indicates that language learners often struggled from speaking anxiety and fear of public speaking whether it is due to judgement of others or their own limited speaking
\end{abstract}




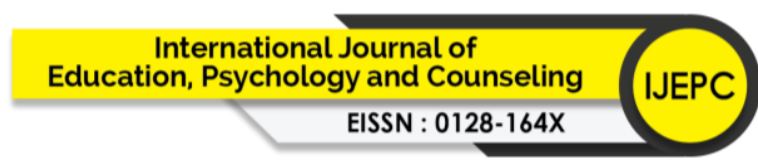

Volume 6 Issue 43 (November 2021) PP. 205-218

DOI 10.35631/IJEPC.643017

Special Issue: Issues and Challenges in English Education

This work is licensed under $\underline{\text { CC BY } 4.0}$

abilities. We have mapped the literature to enable readers to understand the lessons from past literature that can be learned as well as provide a future agenda to the issue.

Keywords:

English Movies, Speaking, Confidence, ESL Learner

\section{Introduction}

Language acquisition necessitates more than just being exposed to the language's linguistic characteristics and communicative components. Media currently penetrates the everyday lives of people of all ages all over the world, according to Bardo et al., (2014). They utilize media devices to communicate, entertain themselves, keep themselves updated, and learn, among other things. Since media is so embedded in our everyday routines, a life without it seems unimaginable. As a result, one of the most obvious features of language acquisition is the incorporation of resources such as English media. The context of media, according to Baidawi (2016), refers to how language learners can use media such as movies that are broadcasted for entertainment as learning content to better understand oral discourse and perform the expected competency of oral discourse. Learning a language through watching or learning from movies that are transmitted in or linked to a certain language can help you become proficient in all areas of the language, notably speaking.

Being able to generate grammatically correct phrases is only one aspect of speaking English. Presenting, persuading, and bargaining abilities, as well as interpersonal skills, are all necessary for effective communication, and all of these talents indicate the candidate's degree of confidence while speaking in English. However, according to Maarof et al., (2015), there has recently been a rising worry over the level of English language competency among Malaysian ESL students. Malaysian ESL students have had 11 to 13 years of formal language teaching in the classroom, yet their speaking skills are still far from ideal (Rusli et. al., 2018). Speaking in front of their classmates is the most common issue learners encounter in terms of speaking confidence; they are frightened of making mistakes and so 'losing face' in front of their classmates and teachers. Many learners have good English language skills, yet they struggle to express themselves while communicating in English. According to Nor et al., (2019), more often than not, ESL learners do not struggle in writing tasks as much as they do with speaking proficiency. Speaking in front of a group of people needs courage, internal motivation, and external stimulants such as a pleasant conversational environment and an interesting topic. Furthermore, some ESL students find particular classmates who are overpowering in their speech to be frightening. They are afraid of saying anything inaccurate or incomprehensible.

Researchers over the years have differing opinions on the current situation. The main objective of the review is to study how English movies can aid ESL learners in higher education who struggle with speaking confidence. The first aspect that we will discuss in this review is the issue of low speaking confidence that is usually caused by language anxiety, lack of self-esteem and fear of judgement among other reasons. In addition to that, we will also investigate further into the research from the databases available for English movies that can be utilized as instructional aid for ESL learners to acquire speaking confidence. We have mapped the literature to enable readers to understand the lessons from past literature that can be learned as 


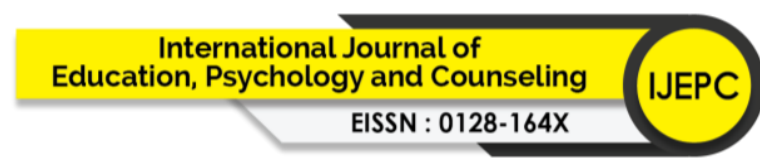

Volume 6 Issue 43 (November 2021) PP. 205-218

DOI 10.35631/IJEPC.643017

Special Issue: Issues and Challenges in English Education

well as provide a future agenda to the issue. Referring to our objective, the research question that arise in this issue are:

1. Can English movies improve ESL learners' speaking confidence?

2. What are the suggested ways to implement English movies in acquiring speaking confidence for ESL learners?

\section{Methodology (Reporting)}

In this systematic literature review, it is important to identify the key terms and phrases in order to answer the research questions. The key terms used to in the databases are "English movies" and "speaking confidence". These key terms were searched through the UMS library access to subscribed databases in order to retrieve relevant articles. This review also includes qualitative and quantitative researches and regard it as valid and eligible as it is free from the author's personal judgements and biases. Therefore, it allows readers to read this review in a fair and objective manner.

\section{Search Strategy}

As part of this systematic review, we devised a search strategy to collect relevant literature. The review was carried out by using the UMS Library's access to subscribed databases. To find relevant research publications, four databases were used: ProQuest, Science Direct, Scopus and JSTOR. The search phrases used in these databases were "English movies" AND "confidence" and "English movies" AND "speaking" in order to acquire a list of relevant research. The searches retrieved from the database are from inception until the year 2021 and it includes journal articles, review paper and research articles.

\section{Selection Criteria}

Initially, there were a total of 7441 relevant articles found by searching the key terms "speaking confidence" and "English movies" in the databases. To get relevant articles, there were a few inclusion criteria that were considered in the search process. The first inclusion criteria is the articles should only be in the English language. There were 6517 articles published in English that were identified at this stage. The second criterion is the access type, where we retrieve articles that allow full access and journals that are subscribed by the university in the databases. After excluding the remaining articles, there were 601 articles extracted at this stage. The third inclusion criterion is the publication year which is to only include articles published within the timeframe of 2016 until 2021. At this stage, there were 284 articles found in the last 5 years. The next inclusion criterion is the document type which is to only include journal articles, review papers and research articles. After excluding other documents such as book chapters, news and conference paper, there were 193 articles left. The other inclusion criterion is to look for articles in the field of Social Sciences, Arts and Humanities and Psychology from the databases which we were able to retrieve 178 articles. The last inclusion criterion is to include articles from the subject area of Language Education, Linguistic and English as a Second Language (ESL). By then, there were a total of 83 articles extracted.

\section{Quality Assessment}




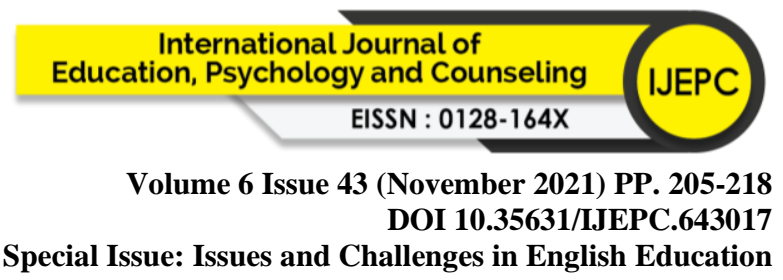

This study is based only on original journal articles, review papers and research articles. In order to maintain the quality of the review, all duplicate records were checked thoroughly and removed from the remaining articles. Abstracts of the articles were ran through for the analysis and purification of the articles to ensure the quality and relevance of academic literature included in review process. A careful evaluation of each research paper was carried out at a later stage. The next step was to filter the papers and keep the most relevant literature out of the 83. There were 71 articles that were deemed unsuitable thus excluded from this study. In the end, a total of 12 relevant articles were retrieved after assessing each article on the aforementioned inclusion and exclusion criteria.

\section{Data Extraction}

In the data extraction phase, 12 articles were selected through the following extraction characteristics:

1. Article must be accessible and are either journal article, review paper and research article. Published reports, case studies, and book chapter were all excluded.

2. The language of the article should be in English language and taken from the field of Social Sciences, Arts and Humanities and Psychology.

3. Articles that were extracted were all published in the past 5 years, between 2016 to 2021.

4. Other criteria includes the specific subject area which are Language, Education and ESL.

The steps and procedures of extracting articles is shown through Table 1 as well as through the flow chart in Figure 1.

Table 1: Inclusion Criteria of Systematic Literature Review

$\begin{array}{lll}\text { Inclusion Criteria } & \text { Item } & \text { Remaining Literatures }\end{array}$

Key Terms

"English movies" AND "speaking"

7441

"English movies" AND “confidence”

Language

English

6517

Access Type

Full Access

601

Publication Year

2016 to 2021

284

Document Type Journal Article, Review Paper and Research Article

193 


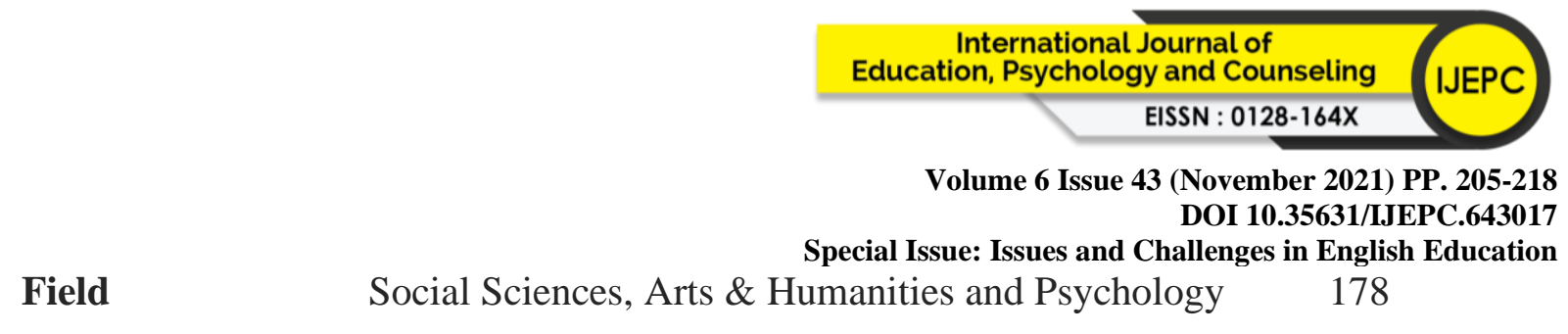

Subject Area

Language, Education and ESL

Table 2: Exclusion Criteria of Systematic Literature Review

\begin{tabular}{lcc}
\hline Exclusion Criteria & Item & Remaining Literatures \\
\hline Relevant Literature & Duplicate/Unsuitable & 8 \\
\hline
\end{tabular}

Figure 1: Flow Chart of Systematic Literature Review

\begin{tabular}{|cc|}
\hline \multicolumn{3}{|c|}{ Inclusion Criteria } \\
\hline English movies and speaking confidence \\
\hline English & 7441 \\
\hline \multicolumn{2}{|c|}{ Language } \\
\hline Full Access/Subscribed & Access Type \\
\hline \multicolumn{2}{|c|}{ Publication Year } \\
\hline 2016 to 2021 \\
\hline Journal article, review paper, research \\
article
\end{tabular}




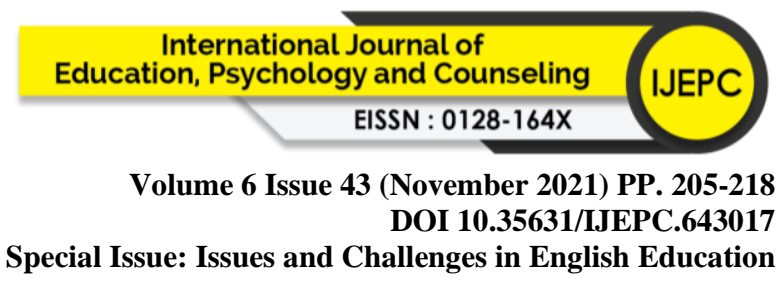

Results And Interpretation

Table 3: Characteristics and Finding of Included Studies

\begin{tabular}{|c|c|c|}
\hline Reference & Intervention & Results \\
\hline $\begin{array}{l}\text { Amoah and } \\
\text { Yeboah (2021) } \\
\text { The Speaking } \\
\text { Difficulties Of } \\
\text { Chinese EFL } \\
\text { Learners And } \\
\text { Their Motivation } \\
\text { Towards } \\
\text { Speaking The } \\
\text { English Language } \\
\text { China } \\
\text { Cited } 0\end{array}$ & $\begin{array}{l}\text { Content: } \\
\text { 1. Chinese EFL } \\
\text { learner's Speaking } \\
\text { Difficulty scale. } \\
\text { 2. Interview. } \\
\text { Duration: } \\
\text { Not specified. } \\
\text { Participants: } \\
75 \text { non-English major } \\
\text { students in the foreign } \\
\text { language department. }\end{array}$ & $\begin{array}{l}\text { The researchers recorded the speaking } \\
\text { problems faced by Chinese EFL learners and } \\
\text { based the findings on linguistic and } \\
\text { psychological factors. It was discovered that } \\
\text { the psychological elements were } \\
\text { mainly speaking anxiety, shyness, and fear of } \\
\text { making mistakes were the most challenging } \\
\text { issues encountered by participants. This } \\
\text { demonstrates a lack of speaking confidence } \\
\text { and self-efficacy. Researchers urge that EFL } \\
\text { learners be encouraged to watch native } \\
\text { English movies in order to establish a desired } \\
\text { setting that will assure English speaking } \\
\text { fluency. }\end{array}$ \\
\hline $\begin{array}{l}\text { Hirci (2016) } \\
\text { Investigating } \\
\text { Trainee } \\
\text { Translators' } \\
\text { Views On The } \\
\text { Pronunciation Of } \\
\text { English: } \\
\text { Slovene } \\
\text { Perspective } \\
\text { Slovenia }\end{array}$ & $\begin{array}{l}\text { Content: } \\
\text { 1. } 15 \text { weekly } 45- \\
\text { minute sessions. } \\
2 . \quad 15 \quad \text { sessions } \\
\text { phonetics classes. } \\
\text { 3. Questionnaire. } \\
\text { Duration: } \\
\text { 15 weeks. } \\
\text { Participants: } \\
57 \quad 1^{\text {st }} \text { year } \\
\text { undergraduate trainee } \\
\text { translators of the } \\
\text { University } \\
\text { Ljubljana. }\end{array}$ & $\begin{array}{l}\text { In the phonetics session, the participants were } \\
\text { exposed to British and English films and } \\
\text { music. An overwhelming majority of } 91 \% \\
\text { participants stated that they expect significant } \\
\text { improvement in pronunciation ability after } \\
\text { taking the English phonetics course. The } \\
\text { participants significantly associate good } \\
\text { pronunciation with unemployment } \\
\text { opportunities since nearly all are confident } \\
\text { that stronger pronunciation abilities lead to } \\
\text { greater employment options. }\end{array}$ \\
\hline $\begin{array}{l}\text { Bolívar-Cruz and } \\
\text { Verano-Tacoronte } \\
\text { (2018) } \\
\text { Self-Assessment } \\
\text { Of The Oral } \\
\text { Presentation } \\
\text { Competence: }\end{array}$ & $\begin{array}{l}\text { Content: } \\
\text { 1. Oral presentation. } \\
\text { 2. Self-assessment } \\
\text { scoring rubric. } \\
\text { Duration: } \\
\text { Not specified. }\end{array}$ & $\begin{array}{l}\text { The study aims to find out how speakers view } \\
\text { their own speaking confidence and public } \\
\text { speaking anxiety. The findings reveal that the } \\
\text { speaker's confidence has a significant impact } \\
\text { on women's self-evaluations score, but not on } \\
\text { men's. The component that has the greatest } \\
\text { impact on women's assessment score as } \\
\text { speakers is their perception of confidence. The }\end{array}$ \\
\hline
\end{tabular}


Volume 6 Issue 43 (November 2021) PP. 205-218

DOI 10.35631/IJEPC.643017

Special Issue: Issues and Challenges in English Education

\begin{tabular}{|l|l|}
\hline Effects Of Gender & Participants: \\
And Student's & $201 \quad$ Business \\
Performance & $\begin{array}{l}\text { Organization students } \\
\text { in a Spanish university. }\end{array}$ \\
Spain &
\end{tabular}

more self-assured they are as speakers, the greater their self-confidence. Men's selfassessment scores, on the other hand, appear to be impacted solely when a reward or incentive is included.

The results suggest that DA, or interactive assessment of teaching and learning, increased non-intellectual characteristics like as interest, motivation, and speaking confidence in the participants. The experiment increased the participants' enthusiasm, with $96.7 \%$ stating their desire to improve English pronunciation and $73.3 \%$ declaring their passion for Standard English pronunciation. $69 \%$ of those polled said they'd prefer to keep practicing imitating English pronunciation in English movies or TV shows. After the trial, $63.3 \%$ also said they were unaffected by other people's perceptions of their pronunciation. The experimental class seemed to have developed confidence in their ability to speak English while also reducing their anxiety.

Sun, Steinkrauss, Content:

Tendeiro and Bot (2016)

Individual

Differences In Very Young Children's

English

Acquisition In

China: Internal

And External

Factors

Netherlands
1. Language aptitude tests: short-term memory and analytical reasoning ability.

$2 . \quad$ Parental questionnaire, interview, and school online records.

Duration:

Not specified.

Participants:

71 Chinese young learners from a private English language institute in Chonqing, China.
During the research, the students were exposed to a variety of English media that they may watch at home, including English TV shows produced in China, English TV shows produced in English-speaking nations, English movies, English audio materials, and English materials on electronic devices. The home English media and home English input were shown to be strongly linked $(r=.80)$ in the findings section. Furthermore, the overall quantity of school input, as well as home English media like cartoons and movies, exhibited significant coefficients (p.05) with the learners' English usage. Home English media showed the highest standardized beta coefficient and partial correlation in terms of productive vocabulary competence. In the end, it is believed that exposure to English media to the young learners help them to improve their limited communication skills. 


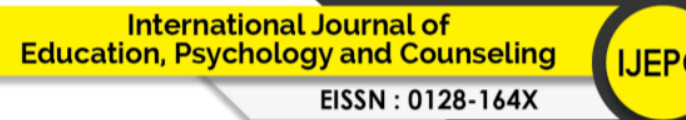

Volume 6 Issue 43 (November 2021) PP. 205-218

DOI 10.35631/IJEPC.643017

Special Issue: Issues and Challenges in English Education

\begin{tabular}{|c|c|c|}
\hline $\begin{array}{l}\text { Albiladi, Abdeen } \\
\text { and Lincoln } \\
(2018) \\
\text { Learning English } \\
\text { through Movies: } \\
\text { Adult English } \\
\text { Language } \\
\text { Learner's } \\
\text { Perceptions } \\
\text { United States }\end{array}$ & $\begin{array}{l}\text { Content: } \\
\text { Semi-structured } \\
\text { interview. } \\
\text { Duration: } \\
\text { 30-60 minutes. } \\
\text { Participant: } \\
25 \text { adult language } \\
\text { learners. }\end{array}$ & $\begin{array}{l}\text { According to the interview findings, roughly } \\
\text { all adult language learners believe that } \\
\text { watching English movies to learn English is } \\
\text { helpful since these films exhibit real-life } \\
\text { language used by native speakers of English. } \\
\text { Learning English through movies not only } \\
\text { allows learners to learn from native speakers, } \\
\text { but it also exposes learners to language, which } \\
\text { aids in language learning. Participants } \\
\text { highlighted that the four major language skills } \\
\text { that may be improved as a result of viewing } \\
\text { movies in particular. The majority of } \\
\text { participants also thought that viewing movies } \\
\text { helped them enhance their speaking and } \\
\text { listening abilities. }\end{array}$ \\
\hline $\begin{array}{l}\text { Boonnoon (2019) } \\
\text { Vocabulary } \\
\text { Learning } \\
\text { Strategies } \\
\text { Employed by Thai } \\
\text { University } \\
\text { Students across } \\
\text { Four Academic } \\
\text { Profiles } \\
\text { Thailand }\end{array}$ & $\begin{array}{l}\text { Content: } \\
\text { Questionnaire. } \\
\text { Duration: } \\
\text { Not specified. } \\
\text { Participant: } \\
300 \text { university students } \\
\text { enrolling in Technical } \\
\text { English course. }\end{array}$ & $\begin{array}{l}\text { Autonomy strategies are closely related to the } \\
\text { learners' motivation and taking responsibility } \\
\text { for their own learning. For example, an } \\
\text { autonomous learner does extensive reading } \\
\text { outside of class or does a variety of out-of- } \\
\text { class activities such as watching English } \\
\text { movies and listening to English stories on } \\
\text { Youtube. }\end{array}$ \\
\hline $\begin{array}{l}\text { The Favored } \\
\text { Language } \\
\text { Learning } \\
\text { Strategies } \\
\text { Islamic } \\
\text { University } \\
\text { Learners }\end{array}$ & $\begin{array}{l}\text { Content: } \\
\text { Duration: } \\
\text { Participant: } \\
18 \text { prospective English } \\
\text { Teachers. }\end{array}$ & $\begin{array}{l}\text { The analysis of the interviews revealed that } \\
\text { individuals used } 59 \text { different techniques to } \\
\text { learn English. One of the primary methods } \\
\text { mentioned by the majority of participants was } \\
\text { watching English television. According to the } \\
\text { participants, they watched movies on } \\
\text { YouTube or on television to enhance their } \\
\text { English skills. This strategy finding is } \\
\text { significant because watching TV or movies } \\
\text { not only improves participants' general } \\
\text { knowledge of English in the areas of } \\
\text { vocabulary, speaking and pronunciation, but it } \\
\text { also provides entertainment through an } \\
\text { interesting way of learning about the culture of } \\
\text { English-speaking countries. }\end{array}$ \\
\hline
\end{tabular}


Volume 6 Issue 43 (November 2021) PP. 205-218 DOI 10.35631/IJEPC.643017

Special Issue: Issues and Challenges in English Education

Figure 2: Distribution of Journals By Year of Publication

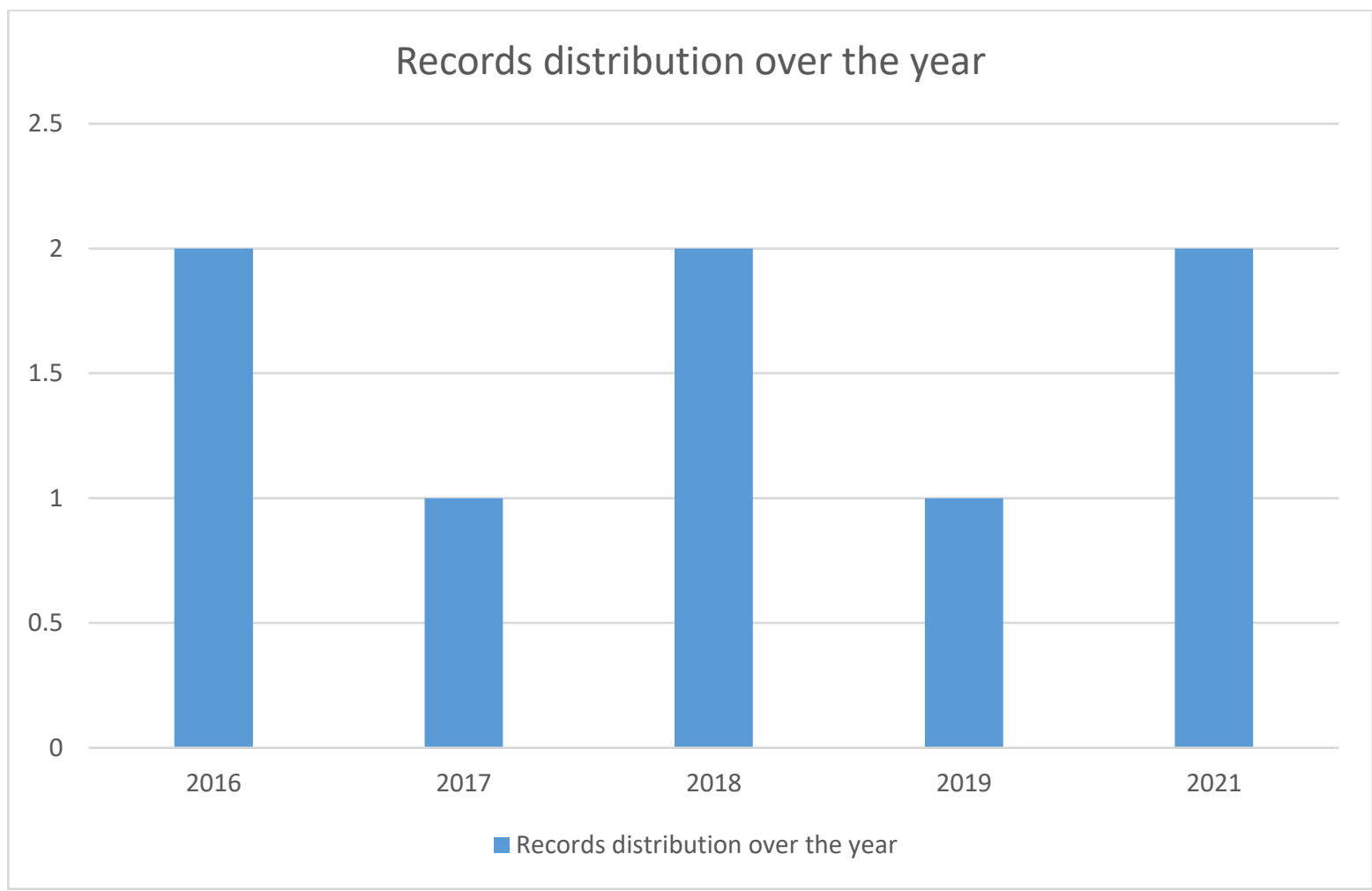




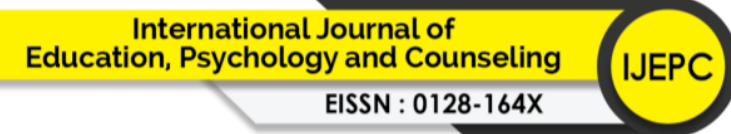

Volume 6 Issue 43 (November 2021) PP. 205-218

DOI 10.35631/IJEPC.643017

Special Issue: Issues and Challenges in English Education

Figure 3: Country with the Most Articles Recorded

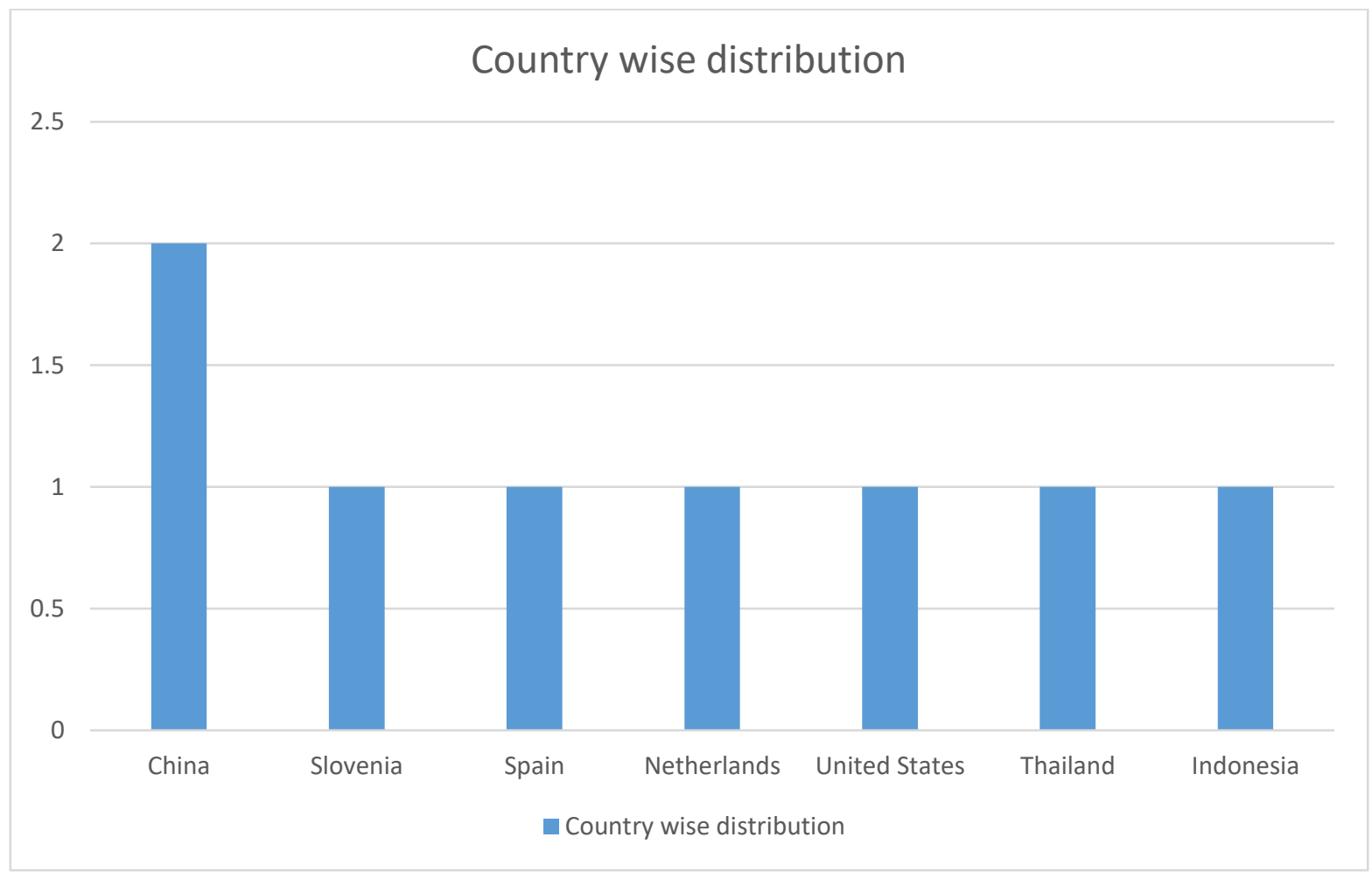

Figure 4: Most Cited Journal Records

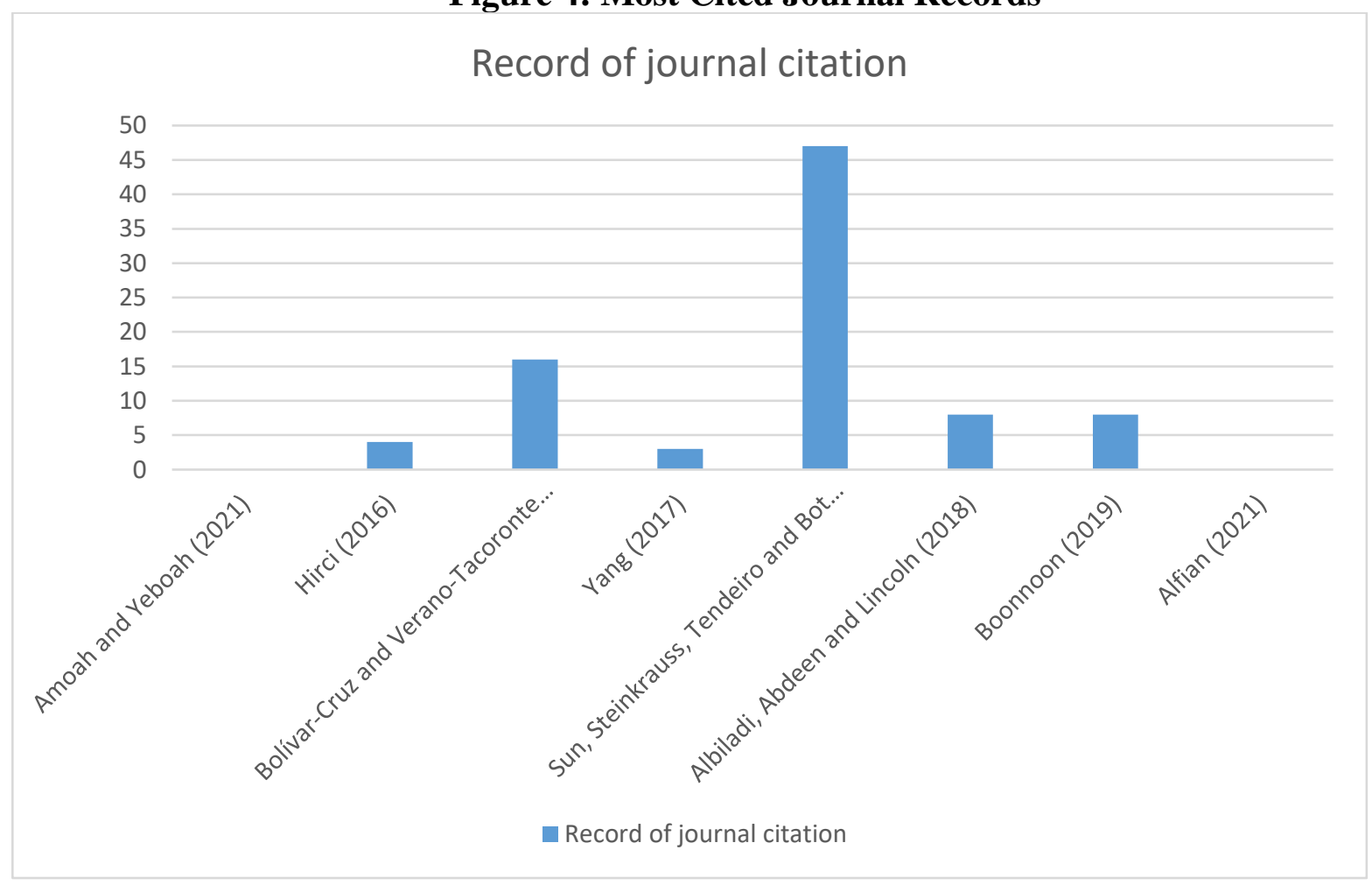

Copyright $\odot$ GLOBAL ACADEMIC EXCELLENCE (M) SDN BHD - All rights reserved 


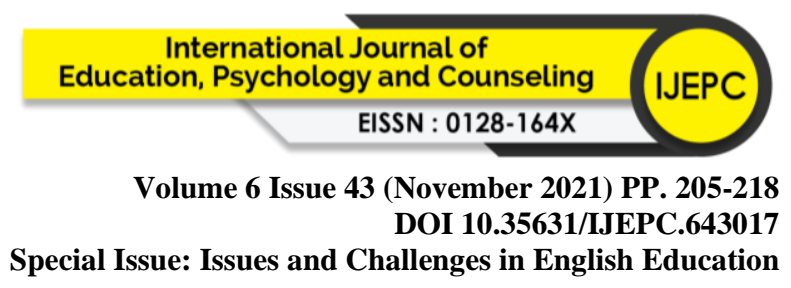

\section{Discussion}

In the discussion section of the review, we will look at the answers to the research question and research objective. The discussion mainly focuses on the factors of English movie that can aid in improving ESL learners' ability in terms of speaking confidence and the factors of English movies that plays a major influence on their speaking confidence. After evaluating the relevant published journals, we can synthesize that the challenges faced by the ESL learner are caused by a number of reasons which will be highlighted in this discussion. We will also look at the factors about English movies that can help aid language learner's speaking ability and confidence. In addition, we will also review the findings to answer the second research question which suggests ways or approach that can be utilized by ESL learners who wish to acquire speaking confidence through English movies.

\section{Ways to Implement English Movies to Acquire Speaking Confidence for ESL Learners}

There are several factors of English movies that may help ESL learners to develop their speaking confidence. Through the findings in the recorded articles, these factors are exhibited as below:

\section{Bolívar-Cruz and Verano-Tacoronte (2018)}

According to the study done by Bolívar-Cruz et. Al. (2018), both men and women experience some level of fear and anxiety when they have to orally communicate which contributes to their lack of confidence in speaking assessments. The finding also suggest that in order to develop learners' ability to evaluate themselves better in public speaking, there should be more assessment activities in the classroom that lets them explore examples of oral presentation such as watching videos or movies in one or more sessions.

\section{Boonnoon (2019)}

The findings in this study demonstrates how learners can get motivation and take responsibility for their own learning. One of the examples of out-of-class activities that can be done by autonomous learners is by learning through instructional materials like watching English movies or additionally, listening to English stories on YouTube. The study also emphasized that these activities can help learners to strengthen their vocabulary learning which can further help them develop their English abilities. However, the instructor or teacher is responsible for choosing the right content in the material used that are suitable if they are teaching students of different major such as science-oriented students or humanities students.

\section{Hirci (2016)}

Once again, the finding by Hirci (2016) states that one of the core of speaking abilities that will enable students to be more confident in speaking is by mastering in pronunciation skills. The finding reports that the majority of language learners agree English films help them improve their pronunciation ability can give them the confidence to communicate better when they seek employment. It was also pointed out that mastering pronunciation enable speakers to have a good sense of evaluation and impression on their own speaking abilities. In essence, when speakers have good self-evaluation and personal impressions on themselves they are expected to perform and excel better at tasks that require speaking and communicating with others, especially an employer. 


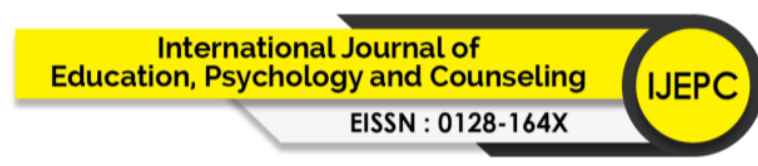

Volume 6 Issue 43 (November 2021) PP. 205-218

DOI 10.35631/IJEPC.643017

Amoah and Yeboah (2021)

Special Issue: Issues and Challenges in English Education

In the study by Amoah et. Al. (2021), the finding highlighted the psychological issues that were faced by Chinese EFL learners. These issues were mainly speaking anxiety, shyness, and fear of making mistakes that were deemed the most challenging aspect that they encounter when it comes to public speaking. The EFL learners demonstrate a lack of speaking confidence and self-efficacy which led researches to conduct the research to find a tool or approach that can become a dominant integrative motivator to enhance their speaking skills and confidence. Researchers suggests in the finding that watching English native movies is in fact a good instrumental motivator for the EFL learners to get rid of their psychological issues when it comes to speaking. On top of that, English native movies are also beneficial and exemplary in order to establish a desired setting that will assure them to converse in English fluently.

\section{Yang (2017)}

The study conducted an experimental classroom that used DA or interactive assessment as the intervention. The results suggested that DA managed to increased participants' interest, motivation, and speaking confidence in the classroom when they implemented English movies and TV series as a form of interactive assessment for the learners to practice their English pronunciation. The experiment proved a successful outcome as it was found that English movies and TV series can in fact improve the participants' overall enthusiasm in the earning activity, with the majority of them agreeing in the questionnaire about their desire to improve English pronunciation and their passion for Standard English pronunciation when the English materials were used. Most of them also agree that they prefer to keep using English movies and TV series to practice imitating English pronunciation. Another major finding was that the participants also said they became more unaffected by other people's perceptions of their pronunciation once they have the English materials to learn from as it was an authentic source of learning. The experimental has seemingly help the learners reduce their speaking anxiety and become more confident in their ability to speak English.

\section{Sun, Steinkrauss, Tendeiro and Bot (2016)}

The study that was done in China highlighted the importance of learning English through watching shows and movies. In the study, learners were exposed to English TV shows that were produced in English-speaking nations, as well as English movies, English audio materials, and English materials that were available in electronic devices. The participants were asked to watch English media at home, including all English TV shows that are produced in China. In the findings, it was shown that the overall quantity of school input, as well as home English media like cartoons and movies, were able to improve the learners' English speaking abilities. The results of the standardized beta coefficient and partial correlation questionnaire also proved that English media showed the highest coefficient in terms of productive vocabulary competence. Hence, exposure to English media towards young learners can help them to improve their limited communication skills.

\section{Albiladi, Abdeen and Lincoln (2018)}

According to the findings of this study, a majority of the young learners who participated in the experiment agree that learning English through watching English movies is a really helpful exercise as it shows the a real-life example of the language used by native speakers of English. This is referred to as learning through imitating authentic source of language. English language exhibited through movies not only allowed the participants to improve their language skill, it 


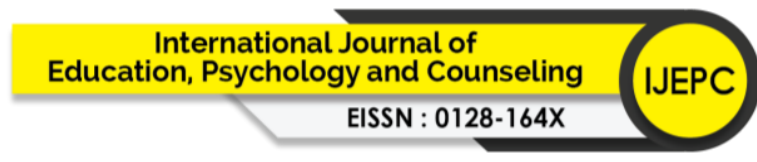

Volume 6 Issue 43 (November 2021) PP. 205-218

DOI 10.35631/IJEPC.643017

Special Issue: Issues and Challenges in English Education also enabled them to feel comfortable enough to converse in the foreign language at an early age. It was also observed that these young learners think English movies can help them improve in the four major language skills in particular. The result from the survey also proved that English movies can indeed help them enhance their ability to speak and listen to English conversations in their daily life.

\section{Alfian (2021)}

The finding that is analyzed from the interviews revealed that the participant prefers learning through English television as one of the primary methods out of 59 different techniques to learn English. They also stated that they enhance their English skills by watching movies on YouTube or English television shows. This strategy discovery is significant because watching TV or movies not only improves participants' general knowledge of English in areas such as vocabulary, speaking, and pronunciation, but it also provides entertainment by providing an interesting way of learning about the culture of English-speaking countries.

\section{Future Agenda}

Based on the discussion, the findings observed in the collected articles are evident towards supporting English movies as a successful tool to developing ESL learners' speaking confidence. The majority of the study indicates that language learners often struggled from speaking anxiety and fear of public speaking whether it is due to judgement of others or their own limited speaking abilities. The articles collected also represent language learners from different age ranges such as young kindergarten learners until university level learners. These findings from the articles proves that English media will be among the variables that can greatly influence learners' motivation to improve their speaking skill and overall confidence. As mentioned by Siska (2013), English movies, are very important assistance for students to learn how to be a good speaker, converse and pronounce words as good as native speakers. This is in fact supported by Liando et al., (2018), who stated that English movies can also provide relevant contexts and vocabulary through natural language delivered at a natural pace. Knowing that English media can be utilized as an instructional tool to improve speaking skill among language learners is a useful information teachers and instructors to create an intervention and expose them to a more interactive and effective approach in the language classroom. As a teacher and instructor, it is important to let learners understand how to gain more confidence by improving their speaking skills and enable them to offer them a unique approach to a learning style. This study also strongly suggests that we can tackle the lack of speaking confidence that has costed the lack of English confidence in ESL learners. The research on relevant articles managed to show the connection between the lack of speaking confidence in ESL learners at tertiary level and the simple use of English movies. Therefore, it is rather important to acknowledge all problems in public speaking anxiety and proposing English media as the variable that can impact ESL learners speaking confidence, as it must be addressed in order for them to engage in better speaking ability.

\section{Reference}

Albiladi, W. S., Abdeen, F. H., \& Lincoln, F. (2018). Learning english through movies: adult english language learners' perceptions. Theory and Practice in Language Studies. = 8(12). 1567-1574. 


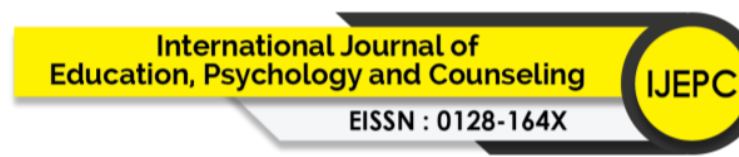

Volume 6 Issue 43 (November 2021) PP. 205-218

DOI 10.35631/IJEPC.643017

Special Issue: Issues and Challenges in English Education

Alfian. (2021). The favored language learning strategies of islamic university efl learners. Studies in English Language and Education. 8(1). 47-64.

Amoah, S., \& Yeboah, J. (2021). The speaking difficulties of Chinese EFL learners and their motivation towards speaking the English language. Journal Of Language And Linguistic Studies. 17(1). 56-69.

Baidawi, A. (2016). Using visual media in teaching speaking. OKARA Journal of Languages and Literature. $1(1)$.

Bardo, H., \& Aßmann, S. (2014). How to define media in a mediatized society? a media pedagogical proposal inspired by theoretical ideas of castells, luhmann andpeirce. Educational Media Ecologies. 24. 18-30.

Bolívar-Cruz, A., \& Verano-Tacoronte, D. (2018). Self-assessment of the oral presentation competence: Effects of gender and student's performance. Studies in Educational Evaluation. 94-101.

Boonnoon, S. (2019). vocabulary learning strategies employed by thai university students across four academic profiles. Theory and Practice in Language Studies. 9(8). 902 910.

Hirci, N. (2016). Investigating trainee translators' views on the pronunciation of english: a slovene perspective. Journal For Foreign Language. 8(1). 93-106.

Liando, N. V. F., Sahetapy, R. J. V., \& Maru, M. G. (2018). English Major Students' Perceptions Towards Watching English Movies In Listening And Speaking Skills Development. Advances in Social Sciences Research Journal, 5(6) 1-16.

Maarof, N., \& Munusamy, I. M. (2015). Learner's Learning Experiences \& Difficulties towards (ESL) among UKM Undergraduates. Advances in Language and Literary Studies. 6(3). 83-87.

Nor, K. M., Razali, M. M., Talib, N., Ahmad, N., Sakarji, S. R., Saferdin, W. A. A. W. M., \& Nor, A. M. (2019). Students' problem in learning english as a second language among MDAB students at UiTM Malacca. International Journal of Humanities, Philosophy, and Language, 2(7), 1-12.

Rusli, R., Yunus, M. M., \& Hashim, H. (2018). Low speaking proficiency among the Malaysian undergraduates: why and how? e-Prosiding Persidangan Antarabangsa Sains Sosial dan Kemanusiaan. 678-689.

Siska, S. S. (2013). Using Film to Increase Motivation for Speaking in English Course Classroom. TELL-US Journal. 1(2). 51-57.

Sun, H., Steinkrauss, R., Tendeiro, J., \& De Bot, K. (2016). Individual differences in very young children's English acquisition in China: Internal and external factors. Bilingualism: Language and Cognition. 19(3). 550-566.

Yang, X. (2017). Dynamic assessment in english pronunciation teaching: from the perspective of intellectual factors. Theory and Practice in Language Studies. 7(9). 780-785. 